\section{Edwin Rosenstiel}

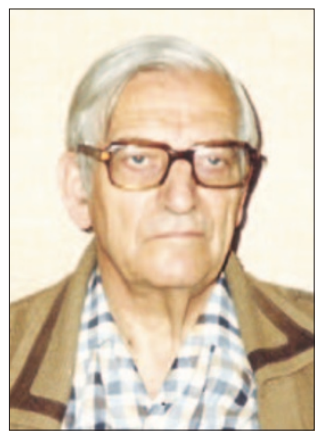

Edwin Rosenstiel died peacefully at his home in Putney on 29 July 2006 aged 93. Born in Berlin on 22 June 1913, Ed had a long, distinguished career in dental education, retiring in 1978 as Reader in Conservative Dentistry and Honorary Consultant at King's College London. After a traumatic childhood, he came to the UK as a student in 1934, decided to switch from mathematics to dentistry, then went back to Germany for a couple of years before returning to England permanently in January 1938. Ed and Connie, his wife, met in Germany in 1934 and married in London in 1940, celebrating 66 years of marriage on 20 April this year. He helped her escape to England in 1939. It goes without saying that those early years were terrible times to be German Jewish, and Ed and Connie worked hard to get people out of the country.

He graduated LDS at Manchester University in 1947. After a Houseman position, he was recruited by Dr Ralph Cocker, Director of the Dental Department at King's, to teach Conservative Dentistry. The Conservative Dentistry Department at King's at that time was located in a converted ward in the main hospital building and his long-time colleagues included Wilfred Collier and Clifford Schreiber and Kenneth Liddelow in prosthetic dentistry. He was much involved in the planning that went into a new purpose-built building that was opened in 1966. Ed applied his interest in mathematics to his academic career. His work on the retention of inlays

\section{...many have spoken of his enormous impact on their philosophy in dentistry.}

and crowns as a function of their geometrical form, which was the basis of his MDS degree awarded by the University of London in 1961, is still cited in prosthodontic textbooks today. One of Ed's distinguished colleagues at King's, Professor Roger Watson, speaks of the assistance Ed provided him early in his career, helping validate Professor Watson's seminal studies on the masticatory function of complete denture wearers.

With his high standards and obsessive personality, his height and his European accent, Ed was initially intimidating to students. However, many have spoken of his enormous lasting impact on their philosophy in dentistry. Many are thankful that they received such superb teaching, particularly in the use of gold alloy. Many of his students have gone on to have distinguished careers, and they acknowledge Ed's role in starting them on their success. They particularly remember his attention to detail - which is so important in restorative dentistry.

After retirement, Ed returned to mathematics and he was awarded the BSc degree by Birkbeck College, University of London in 1983. All their life, Connie and Ed travelled, enjoying trips to Europe and South America long before the era of jet travel. He is survived by his wife Connie, née Meumann, sons Colin and Stephen, three grandchildren and generations of King's dental surgeons.

S. F. Rosenstiel

\title{
Pam Watson
}

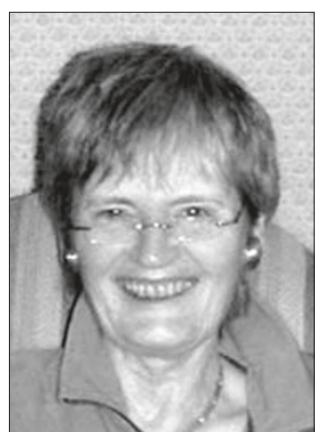

The East Lancs and East Cheshire Branch of the BDA has lost one of its most diligent, committed members with the untimely death on 11 July of Pam Watson at the age of 61 years.

Pamela Lynn Hodson was a native of the North Manchester area. She attended Stand Grammar School and then went on to the Manchester University Dental School, qualifying as a prize winner in 1966. The graduates of that year continue to meet on a regular basis and their condolences were expressed at the 40th anniversary dinner held just five days before her funeral.

After a short period as an associate in Cumbernauld, Pam returned with her husband Robert to the Bury area. Her daughters Fiona and Sarah were born and in between times Pam worked on a part-time basis in several local practices. For some eight years she was an associate in Geoff Wood's practice in Rossendale working alongside Bill Duncalf.

In 1977 Pam was able to open her own practice in Ramsbottom, where in 1996 she had the immense satisfaction of being Vocational Trainer to her own daughter Sarah who continues to practice there as the principal. Pam was soon on the committee of the Burnley Section of the BDA and was eventually elected Chair. This gave her a seat on the Branch Council where she served as President and later, the first Chair. Always courteous, Pam had firm

\section{She always managed to balance the calls of family and practice.}

views on the dento-political issues of the day and was well able to express both her own point of view and that of the meeting as a whole. This was not always easy as there were several senior national BDA figures on Branch Council at that time.

Pam also chaired the Local Emergency Dental Service, was a Dental Practice Adviser and served as a Demonstrator in the Conservation Department of the Manchester Dental School.

Although Pam had an immense commitment to her profession she always managed to balance the calls of family and practice. She had a great interest in good food and fine wines and a weakness for high performance quality motor cars. Family skiing holidays and touring in France were other forms of relaxation.

It was six years ago that Pam's final illness was diagnosed. She had a very positive and optimistic attitude to her surgery and chemotherapy, and insisted that whenever possible she would continue with her career and family commitments. With considerable difficulty she attended the AGM of the Burnley section in March this year. She was an example to us all.

We extend her colleagues' sympathy to her husband Robert, her daughters Fiona and Sarah and the four grandchildren, and also to her parents Fred and Edith who have lost their only child.

G. F. G. 